\author{
Дзядикевич Ю.В. ${ }^{1}$, Захарчук О.П. ${ }^{1}$, Прогній П.Б. ${ }^{1}$, Маяк М.М. ${ }^{2}$, Попович П.В ${ }^{1}$, \\ Шашкевич О.Л. ${ }^{1}$, Коваль Ю.Б. ${ }^{3}$

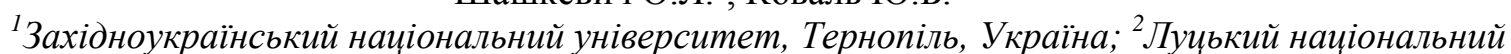 \\ технічний університет, Луцьк, Украйна; ${ }^{3}$ Тернопільський національний технічний університет ім. \\ I. Пулюя, Тернопіль, Україна
}

\title{
ПОШУКОВЕ КОНСТРУЮВАННЯ КОЛІСНИХ ТРАНСПОРТНИХ ЗАСОБІВ
}

\begin{abstract}
Розвинуто дослідження проблематики щодо вироблення критеріїв оцінки показників надійності та довговічності несучих конструкцій колісних транспортних засобів 3 позицій механіки руйнування виходячи 3 факторів їх початкової дефектності у поєднанні 3 експлуатаційними дослідженнями в реальних умовах експлуатації. Проведено структурний аналіз відказів транспортних засобів, що є складовою системи 3 дотримання надійності несучих систем колісних транспортних засобів. Розглянуто концептуальні підходи пошукового конструювання несучих рам засобів транспорту в АПК 3 прогнозуванням ресурсу роботи, обгрунтовано ефективність при вирішенні вказаних аналітично - пошукових і експериментально дослідницьких проблем. Проведено ряд випробувань для визначення динамічних показників у найбільш характерних умовах експлуатації машин. Отримані статистичні дані, які дозволяють, за допомогою аналітичних досліджень, визначити компоненти напруженого стану і характер їх зміни в часі (середні значення, максимальні і мінімальні напруження, їх частоту і т.п.) у відповідності до умов експлуатації. Відносно до отриманих результатів проведено синтез несучих конструкцій через формування таких моделей ресурсу роботи, які адекватно описують процеси, що відбуваються при експлуатації с/г техніки. Такий підхід забезпечує перенесення отриманої експериментальної бази даних (з використанням напрацьованих алгоритмів в динамічній і нелінійній постановці задач) не тільки на проектування розглядуваної конструкції, але і на аналогового типу машин. Забезпечує, в комплексі, прогнозування довговічності з оптимізацією ресурсу роботи, також при модернізації і удосконаленні даного типу конструкцій.

Ключові слова: пошукове конструювання, надійність, прогнозування, ресурс, навантаженість, засоби транспорту.
\end{abstract}

\section{ВСТУП}

Структурний аналіз набору поломок є важливою частиною комплексної системи забезпечення надійності та живучості опорної рами причепа. Зі стратегічної точки зору концепція конструювання несучих систем колісних транспортних засобів з прогнозуванням ресурсу їх роботи, досягає ефекту при проведенні на належному рівні комплексного аналізу несучої здатності несучих металоконструкцій у багатокритеріальному аспекті. Ця концепція $\epsilon$ складним науковим завданням, що вимагає великих експериментальних досліджень стандартних характеристик із використанням методів моделювання при аналізі НДС. Складність у формулюванні стандартів для оцінки міцності та прогнозування терміну служби полягає в у різнопрофільному наборі складових елементів металоконструкцій в поєднанні з специфікою їхніх з'єднань. Оптимізувати такі конструкції складно через відсутність практичних характеристик періодичної стійкості до дефектів, спричинених структурними змінами матеріалів у зоні з'єднання відповідно до конкретних технологій виготовлення (особливо складних зварних стикових з'єднань), а також геометрії поперечних перетинів тонкостінних елементів, відкритого та замкнутого профілю.

\section{АНАЛІЗ ВІДОМИХ РЕЗУЛЬТАТІВ ДОСЛІДЖЕНЬ ТА ПОСТАНОВКА ПРОБЛЕМИ}

Технічні ресурси-показники довговічності, що використовуються для характеристики можливої тривалості робочого часу об'єктів. Відповідно до ГОСТ 27.002-89, ресурс позначається як робота об'єкта з самого початку, або від операції відновлення до початку граничного стану. Відповідно до того, як вибрати час початку, в якій одиниці виміряти тривалість роботи та значення граничного стану, поняття ресурсу приймає різні інтерпретації об'єкта. Як міра тривалості можна вибрати параметр, що характеризує тривалість часу роботи об'єкта. Якщо час роботи вимірюється кількістю виробничих циклів, ресурс отримає дискретні значення. 3 точки зору загальної методології універсальною одиницею є одиниця часу. Перш за все, загалом час роботи технічного об'єкта включає не тільки ефективний час роботи, але й час переривання, протягом якого загальний час роботи 
не збільшується. У цьому процесі руйнування об'єкт буде підданий впливу навколишнього середовища, а навантаження буде створюватися під час транспортування. Крім того, під час процесу руйнування характеристики матеріалу можуть змінюватися (процес старіння матеріалу скорочує загальний термін служби тощо) $[1-4,12,13]$. По-друге, виділені ресурси тісно пов'язані з виділеним терміном служби. Термін служби визначається як календарний термін до зписання об'єкта та вимірюється в календарних одиницях часу. Виділений термін служби багато в чому пов'язаний з науково-технічним прогресом у цій галузі. Використання економічної та математичної моделі, щоб переконатись, що виділені ресурси потрібно не тільки вимірювати з точки зору часу, але й вимірювати ресурси з точки зору календарного часу. По-третє, завдання прогнозування роботи об'єкта в задачі прогнозування решти ресурсів на сегменті є випадковим процесом, а його параметром є час. Отже, ця операція отримує вміст випадкової функції в момент часу $[5,6,12,13]$.

Розглядаючи питання ресурсів сільськогосподарської (сільськогосподарської) техніки, слід враховувати, що більшість сільськогосподарських машин працює в умовах великих динамічних навантажень, вібрації, коливань температури та вологості та підвищеного забруднення. Сезонність сільськогосподарських робіт може спричинити великі навантаження за відносно короткий робочий час. У міжсезоння існує проблема тривалого зберігання. Рівень контролю технологічного процесу та приймання не завжди забезпечує високий рівень точності з'єднання та високий ступінь безвідмовності. Якість умов утримання та зберігання в сільському господарстві нижча, ніж в інших галузях. Ці фактори зменшили тривалість життя більшості сільськогосподарських машин. Крім того, хоча розрахунки, проектування, виготовлення та технічне обслуговування повинні забезпечувати узгодження цих показників, довговічність окремих компонентів сильно варіюється. Тому збільшення ресурсів являє собою значну економію коштів, матеріальних та енергетичних запасів. Отже, збільшення ресурсів автопарку в середньому на $10 \%$ еквівалентно економії близько $10 \%$ на виробництві нових машин. Ресурси значною мірою залежать від навантаження, що діє на машину або елемент конструкції. Правильний підбір матеріалів $\mathrm{i}$ правильні розрахунки $є$ основними джерелами збільшення ресурсів без істотного збільшення вартості механічного проектування. Оскільки прогнозування ресурсів передбачає встановлення залежності від усіх зовнішніх та внутрішніх факторів, розробку методів прогнозування слід розглядати як одну 3 найважливіших наукових галузей загальних ресурсних проблем $[5,7,8,12,13]$. Одним 3 найважливіших, а також найскладніших завдань теорії та практики машинобудування (включаючи сільське господарство) є підвищення надійності (довговічності) конструкції $[1-4,7,9,10,12,13]$. На етапі експлуатації прогнозування ресурсів займе особливе становище. На відміну від фази проектування, при прогнозуванні ресурсів загального набору загальнотехнічних об'єктів, які ще не створені, прогнозування буде виконуватися щодо конкретних існуючих об' єктів на етапі експлуатації. При цьому оцінці підлягають залишковий ресурс і (або) залишковий термін служби.

Залишковий строк корисного використання визначає період очікуваного грошового потоку, тому його вартість буде сильно впливати на оціночну вартість ринку. Більше того, визначення залишкових ресурсів необхідно для визначення залишкової вартості та відповідно визначення вартості заміщення об'єкта. Тому точність оцінки ринкової вартості машин та обладнання значною мірою залежить від того, як правильно визначити залишковий ресурс (залишковий термін служби) об'єкта, що оцінюється. Індивідуальне прогнозування ресурсів відкриває інші шляхи отримання економічних ефектів [10, 12-26]. При прогнозованому проектуванні несучої системи транспортних засобів, що використовуються у сільськогосподарському виробництві, важливо враховувати корозійний вплив металевої конструкції машини $[10,12$-26] за складних умов експлуатації, включаючи транспортні засоби в агресивних сільськогосподарських середовищах, особливо мінеральних речовин. I транспортні засоби з суворим середовищем, органічні добрива, реагенти, засобів для протруювання, ін. [7, 8, 10, 12, 13 -20, 25]

\section{ЦІЛЬ ТА ЗАДАЧІ ДОСЛІДЖЕННЯ}

Через природні відмінності в атрибутах об'єктів та різні умови, в яких вони функціонують (включаючи історію завантаження кожного об'єкта), різні показники ресурсів $\epsilon$ великими. У парку із 108 автомобілів фактичні ресурси для першого капітального ремонту обмежені - від 1,55 до 370000 кілометрів. Окреме прогнозування ресурсів може не тільки 
запобігти можливим збоям та непередбачуваним граничним станам, але також покращити режим роботи, запобіжні заходи та постачання запасних частин. Крім того, перехід до єдиного прогнозу збільшує середній термін служби машини, оскільки це зменшує частку машин, які передчасно вивозяться для ремонту, і відкриває шлях для розумного вибору найкращого терміну експлуатації. У деяких випадках економічно ефективні операції можуть продовжуватися при низьких навантаженнях. Отже можемо розглядати прогнозування індивідуального залишкового ресурсу в якості системи управління процесом експлуатації і технічного обслуговування. Однак запровадження окремих прогнозів вимагає додаткових витрат на технічну діагностику, обладнання для реєстрації рівнів навантаження та стану об'єкта, створення мікропроцесорів для обробки основної інформації, розробку математичних методів та програмного забезпечення для обгрунтування висновків на основі зібраної інформації $[5,7,9,12,13]$. На цій основі необхідно розробити концептуальний метод пошуку та проектування несучої рами транспортних засобів у сільськогосподарських та промислових парках, прогнозування робочих ресурсів та визначення ефективності певних аналітичних проблем пошуку та експериментальних досліджень.

\section{РЕЗУЛЬТАТИ ДОСЛІДЖЕННЯ}

Дослідження надійності тракторного причепа ММЗ-771Б та ММЗ-768Б базується на відповідних експериментальних даних машинної випробувальної станції під час перевірки транспортування. Робоче навантаження становить 2000 годин, і воно становить 50\% загального навантаження при 3500 циклах навантаження - розвантаження. Дослідження проведені на основі 47 напівпричепів ММ3-771 та 15 напівпричепів ММ3-771Б, а також 13 причепів ММ3-768 та 7 причепів ММЗ-768Б, які використовуються для перевезення органічних та мінеральних добрив, а також інших вантажів. У цих таблицях наводяться дані про середній час роботи при відмові основних компонентів цих причепів [7, 8, 10, 12,13].

Таблиця 1. Середній наробіток на відмову основних елементів причепів [12,13].

\begin{tabular}{|c|c|c|c|c|c|c|}
\hline \multicolumn{6}{|c|}{ Середнє напрацювання на відмову ММЗ-771Е і відсоток елементів, які відмовили при } \\
експуатації
\end{tabular}

Середнє напрацювання на відмову ММЗ-771 і відсоток елементів, які відмовили при експлуатації (у дужках)

\begin{tabular}{|c|c|l|c|c|l|c|}
\hline Підвіска & Рама & Ходова & $\begin{array}{l}\text { Гідравлі } \\
\text { ка }\end{array}$ & Гальма & Кузов & $\begin{array}{l}\text { Електроо } \\
\text { бл }\end{array}$ \\
\hline 400 & 437 & 335 & 406 & 512 & 284 & 695 \\
$(53 \%)$ & $(80 \%)$ & $(93 \%)$ & $(80 \%)$ & $(49 \%)$ & $(100 \%)$ & $(35 \%)$ \\
\hline
\end{tabular}

Середнє напрацювання на відмову ММЗ-768Б і відсоток елементів, які відмовили при експлуатації

\begin{tabular}{|c|c|c|c|c|c|c|}
\hline Підвіска & Рама & Ходова & $\begin{array}{c}\text { Гідравлі } \\
\text { ка }\end{array}$ & Гальма & Кузов & $\begin{array}{c}\text { Електроо } \\
\text { бл }\end{array}$ \\
\hline 789 & 753 & 514 & 785 & 646 & 302 & 820 \\
$(53 \%)$ & $(77 \%)$ & $(100 \%)$ & $(100 \%)$ & $(85 \%)$ & $(100 \%)$ & $(100 \%)$ \\
\hline
\end{tabular}

У табл. 1 наведені дані про середній час відмови основних елементів, а також відсотковий еквівалент відмов при напрацюванні в межах 4000 годин.

Тому серед усіх агрегатів найбільше турбує опорна рама, яка є основною одиницею причепа (що становить $12 \%-48 \%$ ваги сільськогосподарської техніки), що знижує загальну продуктивність причепа.

У таблиці 2 узагальнено показники, які забезпечують інформацію про надійність кожного причепа при роботі від 0 до 4000 годин $[7,8,10,12,13]$.

3 табл. 2, бачимо, що фактично на всіх причепах рівень відмов несучої системи становить 22$30 \%$ від терміну служби до основного робочого часу технічного обслуговування. Різні причини переходу металевої конструкції в стан руйнування дозволяють робити висновки про причинність, що веде до руйнування. Основними причинами руйнування металевої конструкції є дефекти на стадії 
виробництва та конструктивні помилки. Відсоток руйнувань через недостатню якість виробництва може досягати більше 60\%. Причинами несправності сільськогосподарської техніки є структурні дефекти на стадії проектування (20-30\%), несправності через низьку якість механічного виготовлення та збірки (20-30\%), низького технічного рівня та якості матеріалів, елементної бази комплектуючих (35-40\%), відмови через порушення правил експлуатації техніки в господарствах та низьку кваліфікацію обслуговуючого персоналу (10\%), інші причини - 5-10\%. [12,13].

Таблиця 2. Показники надійності несучих систем причепів [12,13]

\begin{tabular}{|c|c|c|c|c|c|}
\hline \multirow{2}{*}{ п/п } & Назва показника & $\begin{array}{c}\text { ММ3- } \\
77 \text { IБ }\end{array}$ & $\begin{array}{c}\text { MМ3- } \\
77 \mathrm{I}\end{array}$ & $\begin{array}{c}\text { MM3- } \\
7685\end{array}$ & $\begin{array}{c}\text { MМ3- } \\
768\end{array}$ \\
\hline & Середнє напрацювання на відмову, год. & 545 & 833 & 1176 & 889 \\
\hline $\begin{array}{c}\text { Середня кількість відмов на 1 причіп при } \\
\text { напрацюванні 4000 год. }\end{array}$ & 7,34 & 4,8 & 3,4 & 4,5 \\
\hline & Відсоток причепів, що мали відмови. & 100 & 85 & 77 & 100 \\
\hline
\end{tabular}

У стратегічному плані прогнозування ресурсів навантаження на проектування несучої системи мобільних сільськогосподарських машин результати були досягнуті на необхідному рівні комплексного аналізу несучої здатності несучих металевих виробів у багатостандартних аспектах [7, $8,10,12,13]$.

1. Проблема проектування та виготовлення основних одиниць сільського господарства на сучасному рівні, особливо проблема переміщення основних одиниць, пов'язана $з$ оптимізацією елементів з точки зору основності, базової схематичної геометрії та прогнозування терміну служби. Як ми всі знаємо, практика в сучасному світі полягає головним чином у забезпеченні фіксованої ймовірності відмов для обмежених стійких ресурсів машинної системи, тим самим значно збільшуючи вимоги до точних оцінок похибок ресурсів, може призвести до спонтанного передчасного руйнування , або до завищеної металоємності металоконструкції;

2. Вирішуючи на належному рівні наступні аналітично - пошукові і експериментально дослідницькі проблеми, концепція пошукового конструювання засобів транспорту 3 прогнозуванням ресурсу роботи, досягає ефекту в стратегічному плані;

3. Розвиток нових і систематизація існуючих аналітичних напрацювань з позиції ресурсу роботи конструктивних структур, виходячи 3 енергетичного балансу структури мобільної сүг машини: за механізмами навантаженості металоконструкції формується типологія вузлів і для кожного, на основі першого закону термодинаміки, будуються розрахункові моделі з складанням балансу енергії та зміни швидкості енергії для металоконструкції, подальшим обчисленням швидкості руйнування i, прогнозуванням ресурсу роботи з врахуванням стану матеріалу, його дефектності і всіх фізико-хімічних факторів, які діють на нього при експлуатації машини. Для вирішення проблеми в динамічній формулі необхідно враховувати енергію деформації, спричинену випаданням елементів конструкцій відкритого та закритого профілів. Інтегрований метод, який дозволяє вирішити нелінійну проблему в динамічному процесі залежно від природи грунту, жорсткості підвісу сільськогосподарської техніки тощо;

4. Визначення реальної динаміки навантаженості розглядуваного об'єкта, шляхом проведення грунтовних експериментальних досліджень в умовах експлуатації машин у найбільш характерних рельєфах і кліматичних зонах, з вибором особливостей оброблюваних площ, що $\epsilon$ найбільш трудомісткою i дороговартісною експериментально-дослідницькою проблемою. Наступним процесом є статистична обробка та систематизація отриманих цифрових фактів за допомогою трикомпонентних динамічних характеристик та величини навантаження;

5. Встановлення відповідної основи, тобто формулювання критеріїв для оцінки міцності конструкції або "живучості". Іноземні компанії, що розробляють та виробляють сільськогосподарську техніку з США, Великобританії, Італії, Франції та Німеччини, починають з позиції довговічності проектного циклу та оцінюють довговічність конструкції при втомному руйнуванні на основі факторів їх дефектності (на кафедрі технічної механіки i clг 
машинобудування ТДТУ проводяться такі трудомісткі і дорогі аналітичні та лабораторні випробування та поєднуються з експлуатаційними);

6. Видача оптимізованих параметрів конструкцій (відповідно ефективності вирішення проблеми, п.1, 2, 3) за геометрією поперечних перетинів їх елементів і побудовою принципових схем, 3 прогнозованим ресурсом роботи в цілому на графопобудову, або верстати з ЧПК; формування пакету робочих проектних документів.

Для того, щоб оцінити характер напруженого стану елемента конструкції та визначити метод пошуку його оптимальних параметрів, теоретичний метод визначення коефіцієнта сили в перерізі елемента при повному напруженні $є$ дуже важливим.

При розробці теоретичної основи для аналізу та вирішення складних статично невизначених структур та усунення невідомих зв'язків несучої системи метод, заснований на принципі мінімальної потенційної енергії деформації, та модифікація методу враховують енергію деформації, що генерується вище, у поєднанні з варіаційним принципом Лагранжа, узагальненим принципом додаткової енергії Холлінгена-Рейзнера, методом скінченних елементів, теоремою Кастільяно, мінімальною теоремою роботи, підінтегральною функцією Лейбніца розрахунок закону статичного та динамічного закону $[7,12,13]$ :

$$
U_{\omega}=\sum \int_{l} \frac{B_{\omega}^{2} d s}{2 E I_{\omega}} \text { при системі рівнянь } \frac{\partial U_{\omega}}{\partial B_{\omega_{i}}}=0,
$$

де $B_{\omega}$ - згинально - крутний бімомент, $H \cdot M^{2}$;

$I_{\omega}$ - секторіальний момент інерції, $м^{6}$,

У випадку дії на стрижневу систему динамічного навантаження значення невідомих узагальнених зусиль і переміщень величини визначають з рівнянь $[3,12,13]$

$$
\frac{\partial \Pi}{\partial Q_{i}}=0 ; \frac{\partial \Pi}{\partial q_{i}}=m_{i} \cdot \frac{d^{2} q_{i}}{d t^{2}}
$$

$m_{i}$ - інерційні характеристики мас (маси і моменти інерціі) вузлів системи;

Потім задача вирішується у варіанті для пошуку узагальненої системи переміщень, яка забезпечує найменшу функціональну повну потенційну енергію. Якщо схема розрахунку складається iз скінченного елемента та вузла +1 , то для збіжності всіх осей скінченних елементів функція сумарної потенційної енергії буде мати такий вигляд $[7,12,13]$ :

$$
\begin{aligned}
& \Phi=\sum_{i=0}^{i=1}\left(U_{32}^{(i, i+1)}+U_{n p .}^{(i, i+1)}+U_{c m \kappa}^{(i, i+1)}\right)-\sum_{i=1}^{m}\left(\mid\left(N_{i}-N_{i}^{(i, i-1)}-N_{i}^{(i, i+1)}\right) \bullet U_{x i}+\left(Q_{y i}-Q_{y i}^{(i, i-1)}-Q_{y i}^{(i, i+1)}\right) \bullet U_{y i}\right. \\
& +\left(Q_{z i}-Q_{z i}^{(i, i-1)}-Q_{z i}^{(i, i+1)}\right) \bullet U_{z i}+\left|\left(M_{x i}-M_{x i}^{(i, i-1)}-M_{x i}^{(i, i+1)}\right) \bullet \gamma_{x i}+\right|\left(M_{y i}-M_{y i}^{(i, i-1)}-M_{y i}^{(i, i+1)}\right) \bullet \gamma_{y i}+ \\
& \left.\left(M_{y i}-M_{y i}^{(i, i-1)}-M_{y i}^{(i, i+1)}\right) \bullet \gamma_{y i}+\left(-B_{i}^{(i, i-1)}-B_{i}^{(i, i+1)}\right) \bullet \chi_{i}\right)
\end{aligned}
$$

де $\mathrm{Q}_{\mathrm{zi}}, \mathrm{N}_{\mathrm{i}}, \mathrm{M}_{\mathrm{yi}}, \mathrm{M}_{\mathrm{zi}}, \mathrm{M}_{\mathrm{ki}}, \mathrm{B}_{\mathrm{i}}$-компоненти векторів зовнішнього навантаження, приведеного до базового вузла;

і -номер вузла.

Для визначення фактичного навантаження деталей та конструкцій машини на стадії проектування та випробування зразків в реальних умовах експлуатації дуже важливі експериментальні методи досліджень, які дозволяють отримати надійні дані для оцінки терміну служби машини в умовах випадкового зміни умов [7, 12,13].

Зазвичай сучасні експерименти повинні одночасно реєструвати такі величини, як рух, сила, час, тиск, температура та інші параметри. Тому широко використовувана багатоканальна інформаційно- 
вимірювальна система може отримувати та обробляти інформацію від різних датчиків у режимі реального часу.

Для того, щоб визначити динамічне навантаження, що генерується в реальних робочих умовах машини, розроблено та виготовлено спеціальне вимірювальне обладнання $[3,12,13]$, стандартні та природні зразки, а також обладнання для випробувань на загальному обладнанні (рис. 1). Таким чином, можна скласти тестову програму для визначення динамічних параметрів в найбільш типових робочих умовах. Метод експериментального дослідження в основному реалізується шляхом встановлення спеціального динамометра, наприклад, під опорою основної маси, на осі ходової частини та під опорою штока, насоса, силового агрегату, обприскувача вентилятора, акселерометрів кутових швидкостей (АКШ), акселерометрів прискорень (АП) в центрах мас секцій, а також динамометричних тяг для с〉г причепів, плугів, сівалок, тощо (рис. 2). Виміряні значення записуються в пам'ять мікрокомп'ютера, а потім систематизуються статистична обробка та результати (табл. 3).
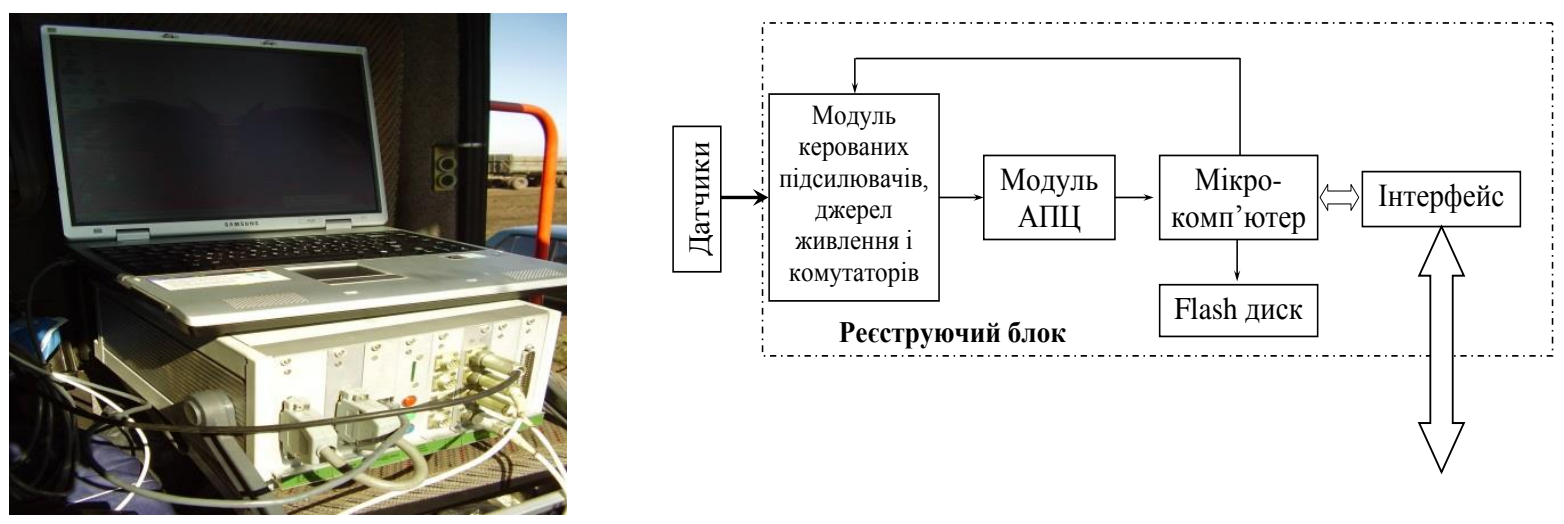

Рисунок 1. Загальний вигляд і принципова схема універсальної вимірюваної системи для дослідження навантаженості мобільних машин $[12,13]$

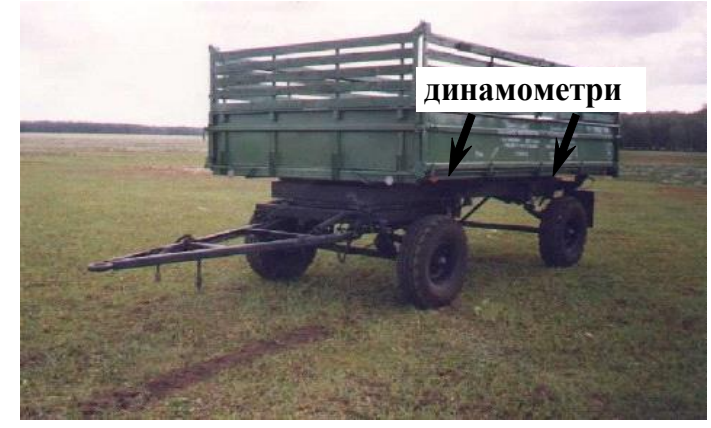

a)

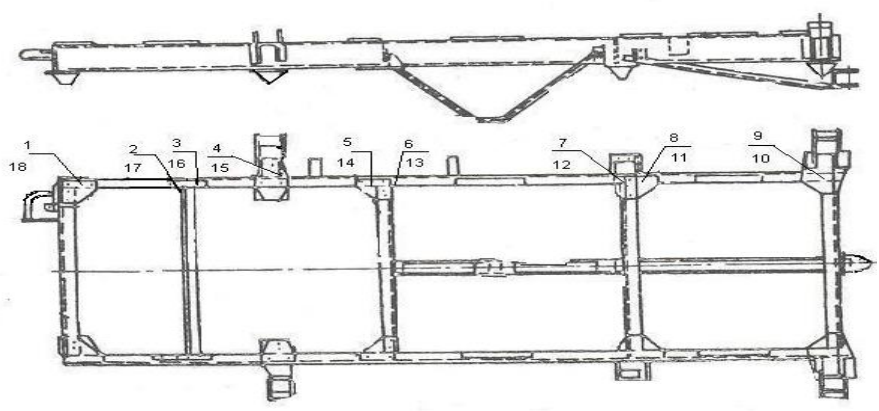

б)

Рисунок 2. Схема розміщення динамометрів (а) і тензодатчиків (б) у тракторному причепі 2ПТС -4 моделі 887Б (ОАО “Механический завод “Калачинский”) [12, 13]

Таблиця 3. Амплітуди змінних напружень тримкої рами причепа тракторного 2ПТС -4 (887Б) $[12,13]$

\begin{tabular}{|r|c|c|c|c|c|c|c|}
\hline \multirow{2}{*}{$\begin{array}{c}\text { № } \\
\text { датчи } \\
\text { ка }\end{array}$} & \multicolumn{2}{|c|}{ Амплітуди напруженнь, МПа } & \multirow{2}{*}{ № } & \multicolumn{3}{|c|}{ Амплітуди напруженнь, МПа } \\
\cline { 8 - 9 } \cline { 7 - 8 } & Мак. & Середн. & Мін. & датчи & Макс. & Середн. & Мін. \\
\hline 1. & $<30$ & - & - & 10 & 98 & 57 & 33 \\
\hline 2. & 38 & 36 & 31 & 11 & 140 & 80 & 35 \\
\hline 3. & 43 & 32 & 30 & 12 & 105 & 52 & 24 \\
\hline 4. & 170 & 77 & 36 & 13 & 127 & 53 & 31 \\
\hline 5. & 118 & 61 & 39 & 14 & 98 & 54 & 26 \\
\hline 6. & 140 & 69 & 35 & 15 & 178 & 87 & 38 \\
\hline
\end{tabular}




\begin{tabular}{|c|c|c|c|c|c|c|c|}
\hline 7. & 117 & 58 & 37 & 16 & 390 & 380 & 360 \\
\hline 8. & 161 & 70 & 38 & 17 & 360 & 340 & 310 \\
\hline 9. & 84 & 49 & 31 & 18 & $<300$ & - & - \\
\hline
\end{tabular}

Випадкові величини реєструються на лазерному диску (можливо, на стрічці), а потім цифрові дані вводяться в пам'ять комп'ютера, а результати статистично обробляються та систематизуються в наступному порядку [7, 12,13]:

-визначити тричастинні динамічні характеристики певних опор, опорних точок, тяг та інших необхідних частин триточкової підвіски трактора;

-згідно з розробленим проектом, провести комплексне вивчення динаміки навантаження способом виконання процесу машинно-тракторного агрегату;

-визначити фактичне напруження кожної контрольної частини шляхом прямого скріплення тензорезистора, тим самим визначаючи, чи достатньо значення аналізу, отримане відповідно до методу;

-аналіз та статистична обробка отриманих результатів для визначення номінального значення динамічних факторів дослідження.

Отримані статистичні дані можуть бути проаналізовані та досліджені для визначення складових напруженого стану та характеру його змінних у часі (середнє значення, максимальне та мінімальне напруження, їх частота тощо) відповідно до умов експлуатації.

На наступному етапі розрахунку дуже зручно аналізувати та вивчати ПДВ конструкції 3 дефектами у вибраному перетині та визначати основні характеристики загального перерізу конструкції проти циклічних дефектів за допомогою експериментів.

\section{ОБГОВОРЕННЯ РЕЗУЛЬТАТІВ ДОСЛІДЖЕНЬ}

Складність розробки стандартів для оцінки міцності та прогнозування терміну служби полягає головним чином у різнопрофільних наборах компонентів цих конструкцій та деталях їх зв'язку між собою. Такі конструкції непросто оптимізувати так як відсутні практичні характеристики періодичної дефектної стійкості, спричиненої структурними змінами матеріалів в районі шва відповідно до конкретних технологій виготовлення (особливо складних зварних стикових стиків).

Впровадження методу формулювання критеріїв оцінки міцності конструкції та прогнозування строку служби конструкції схематично здійснюється в наступному порядку $[12,13]$ :

1. Вивчити динаміку розвитку дефектів природних елементів конструкції (таких як розрідженість каркаса).

2. Отримати аналітичну кореляцію opening-розриву руйнування, що використовується для визначення коефіцієнта інтенсивності напружень (КІН), $\delta$ - розкриття тріщин.

3. Визначити дефектні характеристики металевої конструкції.

4. Побудувати діаграми руйнування натурних профілів, наприклад. лонжеронів рам 3 поперечинами;

5. Беручи до уваги особливості структури та зміну властивостей металу в процесі розвитку тріщини (межа міцності тощо), отримують залежність прогнозованої міцності.

6. Беручи до уваги залишкове напруження від додаткового коефіцієнта сили, отримаємо теоретичну залежність критеріїв оцінки для визначення тонкостінних відкритих і закритих контурів елемента конструкції; побудова емпіричної автомоделі подібності.

Відповідно до отриманих параметрів, проводиться машинне конструювання, включаючи особливості:

1. взаємозв'язок між процедурами формування та читання креслень;

2. метод єдиного параметра для опису геометричних об'єктів та їх зображень;

3. у процесі алгоритмічного зв'язку існують основні категорії геометричних та графічних задач.

4. Опублікуйте оптимізовані параметри для графічного побудови та сформуйте набір робочих проектних документів.

Викладені матеріали ефективно спрацювали при розробці найскладнішої с/г техніки в динамічній постановці задач.

\section{ВИСНОВКИ}

Аналітичні дослідження НДС структурних елементів всієї конструкції з застосуванням МКЕ можуть бути Основними етапами комплексного аналізу тримкої здатності. Успішно застосовано вдосконалений метод мінімізації потенційної енергії деформації, що дало можливість для ПДВ- 
моделювання міцних каркасів з урахуванням усіх типів навантаження. Для кожного компонента у багатокритеріальному твердженні розраховано комплексний індекс навантаження.

Метод формування стандарту для оцінки несучої здатності та прогнозування терміну служби конструкції повинен бути реалізований у наступному порядку:

•отримати аналітичну кореляцію для визначення коефіцієнта інтенсивності напружень (КІН) i дельта-розкриття тріщин для відкритих та замкнутих холодноформованих i гарячекатаних тонкостінних профілів;

•чітко визначити залежність КІН для тріщин, що утворюються в зоні впливу теплоти, яка $є$ функцією структурної концентрації напруги, залишкового зварювального напруження та неоднорідності зварювальних матеріалів;

Щодо отриманих результатів, несуча конструкція синтезується шляхом формування такої моделі терміну служби, яка повністю описує процеси, що відбуваються під час роботи сільськогосподарської техніки.

Обклеювання певних конструкцій (наприклад авіаторів, автомобілістів та інших проектних організацій мобільного машинобудування) і визначення їх напружено - деформівного стану не раціонально і малоефективно. Найбільш раціональним та ефективним процесом $\epsilon$ визначення реальної циклічної навантаженості в опорах або кріпленнях конструктивної системи, за допомогою встановлення спеціальних вимірювальних пристроїв, з паралельною наклейкою тензорезисторів лише у контрольних перетинах Цей метод може не тільки перенести отриману експериментальну базу даних (використовуючи розроблений алгоритм у динамічному та нелінійному поданні задачі) на структурну конструкцію, але також і на аналогового типу машин. У складних ситуаціях прогнози довговічності можуть бути надані шляхом оптимізації робочих ресурсів, а також модернізації та вдосконалення таких конструкцій.

\section{ПЕРЕЛІК ДЖЕРЕЛ ПОСИЛАННЯ}

1.Гуков Я.С. Проблеми вітчизняного сільськогосподарського машинобудування та шляхи їх вирішення//Техніка АI ІК. 2006. -№ 5.-С. 12.

2.Шебанін В.С. Перспективи розвитку сільськогосподарського машинобудування в Україні // Вісник агра науки Причорномор'я. - 2007. - № 2 (41). - С. 3-10.

3.Кравчук В. Пріоритетні напрямки наукових досліджень при прогнозуванні, випробуванні та сертифікації техніки і технологій АПК//Техніка АПК. - 2008. -№ 1.-С. 6-7.

4.Погорелый Л.В., Анилович В.Я. Испытания сельскохозяйственной техники: научнометодические основы оценки прогнозирования надежности сельскохозяйственных машин. Феникс, 2004. - 208 с.

5.В.В. Болотин. Прогнозирование ресурса машин и конструкций. -M. Машиностроение, 1984.-312с. :ил.

6.М. Черновол, С. Гранкін, В. Малахов, В. Черкун. Надійність с/г техніки.- К.: Урожай, 1998. -208с.: іл.

7.Рибак T.I. Пошукове конструювання на базі оптимізації ресурсу засобів транспорту . Підручник-посібник. Тернопіль. "Збруч”, 2003.-332c.

8.Щурин К.В. Прогнозирование и повышение усталостной долговечности несущих систем сельськохозяйственных транспортных средств.// Автореф. дис. докт. техн. наук. 05.20.01. Оренбург. - 1994. - 46c.

9.Тимочко В. О. Ідентифікація транспортних засобів у проектах сільськогосподарського виробництва / В. О. Тимочко, Р. І. Падюка, І. М. Городецький // Вісник Національного технічного університету "ХПІ". Серія: Стратегічне управління, управління портфелями, програмами та проектами $=$ Bulletin of the National Technical University "KhPI". Series: Strategic management, portfolio, program and project management : зб. наук. пр. - Харків : НТУ "ХПІ", 2018. - № 1 (1277). - С. 75-79.

10.Попович П.В. Комплексний аналіз надійності несучих систем тракторних причепів при їхній експлуатації //Попович П.В, Рибак Т.I./ Механізація сільськогосподар- ського виробництва. - Вісник ХНТУСГ, Вип. 93 Харків, 2010. - С. 411-414.

11.Попович П.В. Алгоритм оцінки базових експлуатаційних властивостей колісних сільськогосподарських транспортних засобів / Попович П., Шевчук О., Ляшук О.Л., Матвіїшин А.Й. // Вісник ХНТУСГ. - Харків, 2017. - Вип. № 181. - С. 198 - 203. 
12.T. I. Рибак. Концепція пошукового конструювання мобільної техніки в АПК / Т. І. Рибак, П. В. Попович, М. Я. Сташків // Конструювання, виробництво та експлуатація сільськогосподарських машин. - 2009. - Вип. 39. - С. 40-47. - Режим доступу: http://dspace.kntu.kr.ua/jspui/bitstream/123456789/2591/1/7.pdf

13.Рибак Т. І. Аналіз надійності несучих систем тракторних причепів [Електронний pecypc] / Т. І. Рибак, П. В. Попович, Ю. В. Грицай, Н. Рубінець // Вісник Харківського національного технічного університету сільського господарства імені Петра Василенка. 2014. - Вип. 151. - С. 18-20. - Режим доступу: http://nbuv.gov.ua/UJRN/Vkhdtusg_2014_151_5

14.YA. DOROSHENKO, V. ZAPUKHLIAK, YA. GRUDZ, et al., Numerical simulation of the stress state of an erosion-worn tee of the main gas pipeline. Archives of Materials Science and Engineering 101/2 (2020) 63-78. ISSN 1897-2764. Available from: https://doi.org/10.5604/01.3001.0014.1192

15.POPOVYCH P, LYASHUK O, SHEVCHUK O, et al. Influence of organic operation environment on corrosion properties of metal structure materials of vehicles. INMATEH - Agric Eng. 2017;52(2):113-118. ISSN 2068-4215, eISSN 2068-2239. Available from: https://inmateh.eu/ volumes/old-volume/volume-52-no-2-2017/article/influence-of-organicoperation-environment-on-corrosion-propertiesof-metal-structure-materials-of-vehicles.

16.POPOVYCH P, LYASHUK O, MUROVANYI I, et al. The service life evaluation of fertilizer spreaders undercarriages. INMATEH - Agric Eng. 2016;50(3):39-46. ISSN 2068-4215, eISSN 2068-2239. Available from: https://inmateh.eu/volumes/old-volume/volume-50-no-3-2016/ article/the-service-life-evaluation-of-fertilizer-spreaders-undercarriages

17.LYTVYNENKO, I.V., MARUSCHAK, et al., Modeling of the Ordered Surface Topography of Statically Deformed Aluminum Alloy. Mater Sci (2016) 52: 113-122. Materials Science [online]. 2016, 52, p. 113-122. ISSN 1068-820X, eISSN 1573-885X. Available from: https://doi.org/10.1007/s11003-016-9933-1

18.BARNA R. A., POPOVICH P. V. Influence of Operating Media on the Fatigue Fracture of Steels for Elements of Agricultural Machines. Materials Science. - 2014.- Vol. 50, 3. - pp. 377-380. ISSN 1068-820X, eISSN 1573-885X. Available from: https://doi.org/10.1007/s11003014-9729-0

19.HEVKO B.M., DIACHUN A.Y., LYASHUK O.L., et al. (2015), The study of bulk material kinematics in a screw conveyor-mixer, INMATEH Agricultural Engineering, vol.47, no.3., pp. 156-163

20.P POPOVYCH, L POBEREZHNY, O SHEVCHUK, I MUROVANYI, et al. (2020). Evaluation of strength of carrying metal structures of trailers. Journal of Achievements of Materials and Manufacturing Engineering 2(100): 58-69. Available from: https://doi.org/10.5604/01.3001.0014.3345.

21.POPOVYCH, P.; SHEVCHUK, O.; DZYURA, V.; et al: Assessment of the influence of corrosive aggressive cargo transportation on vehicle reliability. International Journal of Engineering Research in Africa 2018, 38, 17-25. ISSN 1663-3571, eISSN 1663-4144. Available from: https://doi.org/10.4028/www.scientific.net/JERA.38.17

22.POPOVYCH PV, DZYURA V, \& SHEVCHUK OS. Reliability estimation of transport means elements under the action of cyclic loads and corrosive environment. Int. J. of Automotive and Mechanical Engineering 2018;15(4):5793 -5802. ISSN: 2229-8649 (Print); 2180-1606 (Online) Available from: https://doi.org/10.15282/ijame.15.4.2018.6.0443

23.B. SOKIL, O. LYASHUK, M. SOKIL, et al. Dynamic Effect of Cushion Part of Wheeled Vehicles on Their Steerability", International Journal of Automotive and Mechanical Engineering, vol. 15, no. 1, pp. 4880-4892, 2018. Available from: https://doi.org/10.15282/ijame.15.1.2018.1.0380

24.P POPOVYCH, L POBEREZHNY, O SHEVCHUK, et al. (2020), Corrosion-fatigue failure of tractor trailers metal materials in aggressive environments, Koroze a Ochrana Materialu 64/2 (2020) 45-51. Online ISSN: 1804-1213. Available from: https://doi.org/10.2478/kom-20200007

25.Popovych, P.V., Mahlatyuk, L.A. \& Kupovych, R.B. Influence of Organic Fertilizers on the Corrosion-Electrochemical Characteristics of Low-Carbon Steels. Mater Sci 50, 284-289 (2014). https://doi.org/10.1007/s11003-014-9719-2 
26.Popovych, P.V., Slobodyan, Z.B. Corrosion and Electrochemical Behaviors of 20 Steel and St.3 Steel in Ammonium Sulfate and Nitrophoska. Mater Sci 49, 819-826 (2014). https://doi.org/10.1007/s11003-014-9679-6

27.Barna, R.A., Popovych, P.V. \& Vovk, R.I. Influence of the Working Media on the Cyclic Crack Resistance of Steels for Elements of Agricultural Machines. Mater Sci 50, 621-625 (2015). https://doi.org/10.1007/s11003-015-9762-7

\section{REFERENCES}

1.Gukov Ya.S. (2006). Problemy vitchyznyanoho sil's'kohospodars'koho mashynobuduvannya ta shlyakhy yikh vyrishennya. Tekhnika AI IK, 5, 12.

2.Shebanin V.S. (2007). Perspektyvy rozvytku sil's'kohospodars'koho mashynobuduvannya v Ukrayini. Visnyk ahra nauky Prychornomor'ya, 2 (41), 3-10.

3.Kravchuk V. (2008). Priorytetni napryamky naukovykh doslidzhen' pry prohnozuvanni, vyprobuvanni ta sertyfikatsiyi tekhniky i tekhnolohiy APK. Tekhnika APK, 1, 6-7.

4.Pogorelyy L.V. \& Anilovich V.YA. (2004). Ispytaniya sel'skokhozyaystvennoy tekhniki: nauchno-metodicheskiye osnovy otsenki prognozirovaniya sel'skokhozyaystvennykh mashin. Feniks, 208.

5.Bolotin V.V. (1984). Prognozirovaniye resursa mashin i konstruktsiy. M. Mashinostroyeniye, 312.

6.Chernovol M., Hrankin S., Malakhov V., \& Cherkun V. (1998). Nadiynist' s/h tekhniky, Urozhay, 208.

7.Ribak T.I. (2003) Poshukove konstruyuvannya na bazí optimízatsîi resursu zasobív transportu. Zbruch, 332.

8.Shchurin K.V. (1994). Prognozirovaniye i povysheniye dolgovechnosti nesushchikh sistem sel's'kokhozyaystvennykh transportnykh sredstv. dis. dokt. tekhn. nauk. 05.20.01. Orenburg. 469s.

9.Timochko V.O., Padyuka R. Í. \& Gorodets'kiy Í. M. (2018). Identifikatsiya transportnykh sredstv v proyektakh sel'skokhozyaystvennogo proizvodstva. Visnyk natsional'noho tekhnichnoho universytetu "KHPI". Seriya: Stratehichne upravlinnya, upravlinnya portfelyamy, prohramamy ta proektamy $=$ Bulletin of the National Technical University "KhPI". Series: Strategic management, portfolio, program and project management : zb. nauk. pr. - Kharkiv: NTU "KHPI", 1 (1277), 7579.

10.Popovych P.V. \& Rybak T.I. (2010). Kompleksnyy analiz nadiynosti nesuchykh system traktornykh prychepiv pry yikhniy ekspluatatsiyi. Mekhanizatsiya sil's'kohospodar- s'koho vyrobnytstva. Visnyk KHNTUS·H, 93, 411-414.

11.Popovych P.V., Shevchuk O., Lyashuk O.L. \& Matviyishyn A.Y. (2017). Alhorytm otsinky bazovykh ekspluatatsiynykh vlastyvostey kolisnykh sil's'kohospodars'kykh transportnykh zasobiv. Visnyk KHNTUS·H., 181, 198 - 203.

12.TI Rybak. Koncepciya poshukovogo konstruyuvannya mobil`noyi texniky` v APK / TI Rybak, PV Popovych, M. Ya. Stashkiv // Design, production and operation of agricultural machines. - 2009. - Vip. 39. - P. 40-47. - Access mode: http://dspace.kntu.kr.ua/jspui/bitstream/123456789/2591/1/7.pdf

13.Rybak TI Analiz nadijnosti nesuchy`x sy`stem traktorny`x pry`chepiv / TI Rybak, PV Popovych, Yu. V. Hrytsai, N. Rubinets // Visnyk of Kharkiv National Technical University of Agriculture named after Petro Vasylenko. - 2014. - Vip. 151. - P. 18-20. - Access mode: http://nbuv.gov.ua/UJRN/Vkhdtusg_2014_151_5

14.YA. DOROSHENKO, V. ZAPUKHLIAK, YA. GRUDZ, et al., Numerical simulation of the stress state of an erosion-worn tee of the main gas pipeline. Archives of Materials Science and Engineering 101/2 (2020) 63-78. ISSN 1897-2764. Available from: https://doi.org/10.5604/01.3001.0014.1192

15.POPOVYCH P, LYASHUK O, SHEVCHUK O, et al. Influence of organic operation environment on corrosion properties of metal structure materials of vehicles. INMATEH - Agric Eng. 2017;52(2):113-118. ISSN 2068-4215, eISSN 2068-2239. Available from: https://inmateh.eu/ volumes/old-volume/volume-52-no-2-2017/article/influence-of-organicoperation-environment-on-corrosion-propertiesof-metal-structure-materials-of-vehicles. 
16.POPOVYCH P, LYASHUK O, MUROVANYII, et al. The service life evaluation of fertilizer spreaders undercarriages. INMATEH - Agric Eng. 2016;50(3):39-46. ISSN 2068-4215, eISSN 2068-2239. Available from: https://inmateh.eu/volumes/old-volume/volume-50-no-3-2016/ article/the-service-life-evaluation-of-fertilizer-spreaders-undercarriages

17.LYTVYNENKO, I.V., MARUSCHAK, et al., Modeling of the Ordered Surface Topography of Statically Deformed Aluminum Alloy. Mater Sci (2016) 52: 113-122. Materials Science [online]. 2016, 52, p. 113-122. ISSN 1068-820X, eISSN 1573-885X. Available from: https://doi.org/10.1007/s11003-016-9933-1

18.BARNA R. A., POPOVICH P. V. Influence of Operating Media on the Fatigue Fracture of Steels for Elements of Agricultural Machines. Materials Science. - 2014.- Vol. 50, 3. - pp. 377-380. ISSN 1068-820X, eISSN 1573-885X. Available from: https://doi.org/10.1007/s11003014-9729-0

19.HEVKO B.M., DIACHUN A.Y., LYASHUK O.L., et al. (2015), The study of bulk material kinematics in a screw conveyor-mixer, INMATEH Agricultural Engineering, vol.47, no.3., pp. 156-163

20.P POPOVYCH, L POBEREZHNY, O SHEVCHUK, I MUROVANYI, et al. (2020). Evaluation of strength of carrying metal structures of trailers. Journal of Achievements of Materials and Manufacturing Engineering 2(100): 58-69. Available from: https://doi.org/10.5604/01.3001.0014.3345.

21.POPOVYCH, P.; SHEVCHUK, O.; DZYURA, V.; et al: Assessment of the influence of corrosive aggressive cargo transportation on vehicle reliability. International Journal of Engineering Research in Africa 2018, 38, 17-25. ISSN 1663-3571, eISSN 1663-4144. Available from: https://doi.org/10.4028/ www.scientific.net/JERA.38.17

22.POPOVYCH PV, DZYURA V, \& SHEVCHUK OS. Reliability estimation of transport means elements under the action of cyclic loads and corrosive environment. Int. J. of Automotive and Mechanical Engineering 2018;15(4):5793 -5802. ISSN: 2229-8649 (Print); 2180-1606 (Online) Available from: https://doi.org/10.15282/ijame.15.4.2018.6.0443

23.B. SOKIL, O. LYASHUK, M. SOKIL, et al. Dynamic Effect of Cushion Part of Wheeled Vehicles on Their Steerability", International Journal of Automotive and Mechanical Engineering, vol. 15, no. 1, pp. 4880-4892, 2018. Available from: https://doi.org/10.15282/ijame.15.1.2018.1.0380

24.P POPOVYCH, L POBEREZHNY, O SHEVCHUK, et al. (2020), Corrosion-fatigue failure of tractor trailers metal materials in aggressive environments, Koroze a Ochrana Materialu 64/2 (2020) 45-51. Online ISSN: 1804-1213. Available from: https://doi.org/10.2478/kom-20200007

25.Popovych, P.V., Mahlatyuk, L.A. \& Kupovych, R.B. Influence of Organic Fertilizers on the Corrosion-Electrochemical Characteristics of Low-Carbon Steels. Mater Sci 50, 284-289 (2014). https://doi.org/10.1007/s11003-014-9719-2

26.Popovych, P.V., Slobodyan, Z.B. Corrosion and Electrochemical Behaviors of 20 Steel and St.3 Steel in Ammonium Sulfate and Nitrophoska. Mater Sci 49, 819-826 (2014). https://doi.org/10.1007/s11003-014-9679-6

27.Barna, R.A., Popovych, P.V. \& Vovk, R.I. Influence of the Working Media on the Cyclic Crack Resistance of Steels for Elements of Agricultural Machines. Mater Sci 50, 621-625 (2015). https://doi.org/10.1007/s11003-015-9762-7

\section{Y. Dziadykevych, O. Zakharchuk, P. Prohnii, M. Maiak, O. Shashkevych, Y. Koval. Search design of vehicles in agro-industrial complex}

The research of problems on estimation criteria development of reliability indicators and durability of transport unibody constructions for agricultural production from the point of view of destruction mechanics proceeding from factors of their initial defect in combination with field investigations under actual operating conditions has been developed. It has been carried out the structural analysis of failures of vehicles which are system components on observance of reliability of transport unibody constructions of wheeled vehicles. Conceptual approaches of search design of construction frames of transport means in agrarian and industrial complex with work resource forecasting are considered, efficiency at the decision of the specified analytical and research and experimental and research problems is proved. A number of tests were performed to determine the dynamic parameters in the most characteristic operating conditions of machines. The obtained 
statistical data, which allow, with the help of analytical studies, to determine the components of the stress state and the nature of their change over time (average values, maximum and minimum stresses, their frequency, etc.) in accordance with operating conditions. According to the obtained results, the synthesis of load-bearing structures through the formation of such models of service life, which adequately describe the processes occurring during the operation of agricultural machinery was conducted. This approach ensures the transfer of the obtained experimental database (using the developed algorithms in the dynamic and nonlinear formulation of problems) not only to the design of the structure, but also to the analog type of machines. It provides, in combination, forecasting durability optimization of resources, and the modernization and improvement of this type of structures.

Key words: search design, reliability, forecasting, resource, load, transport means.

ДЗЯДИКЕВИЧ Юрій Володимирович, доктор технічних наук, професор, Західноукраїнський національний університет, Тернопіль, Україна, e-mail: yu.dziadykevych @wunu.edu.ua, https://orcid.org/ 0000-0002-3737-9347

ЗАХАРЧУК Олена Павлівна, кандидат технічних наук, доцент, доцент кафедри транспорту і логістики, Західноукраїнський національний університет, Тернопіль, Україна, e-mail: olenaskyba8500@gmail.com. https://orcid.org/0000-0001-9452-9850

ПРОГНІЙ Павло Богданович, кандидат технічних наук, ст.викл. кафедри спеціалізованих комп'ютерних систем, Західноукраїнський національний університет, Тернопіль, Україна, е-таil: PPopovuch@gmail.com

МАЯК Микола Михайлович, доктор технічних наук, професор, професор кафедри автомобілів і транспортних технологій, Луцький національний технічний університет, Луцьк, Україна, e-mail: maiak48@mail.ru

ПОПОВИЧ Павло Васильович, доктор технічних наук, професор, професор кафедри транспорту і логістики, Західноукраїнський національний університет, Тернопіль, Україна, e-mail: PPopovich@ukr.net. https://orcid.org/0000-0001-5516-852X

ШАШКЕВИЧ Олександр Любомирович, кандидат економічних наук, доцент, доцент кафедри фінансів ім. С.І. Юрія, Західноукраїнський національний університет, Тернопіль, Україна, e-mail: o.shashkevych@wunu.edu.ua . http://orcid.org/ 0000-0003-3642-1643

КОВАЛЬ Юрій Богданович, аспірант кафедри транспортних технологій та механіки, Тернопільський національний технічний університет, Тернопіль, Україна, e-mail: PPopovich@ukr.net.

Yurii DZIADYKEVYCH, Doctor of Sciences, Professor, West Ukrainian National University, Ternopil, Ukraine, e-mail: yu.dziadykevych@wunu.edu.ua. https://orcid.org/ 0000-0002-3737-9347

Olena ZAKHARCHUK, Doctor of Philosophy, Associate Professor of Transport and Logistics department, West Ukrainian National University, Ternopil, Ukraine, e-mail: olenaskyba8500@gmail.com. https://orcid.org/0000-0001-9452-9850

Pavlo PROHNII, Doctor of Philosophy, Senior Lecturer of Specialized Computer Systems department, West Ukrainian National University, Ternopil, Ukraine, e-mail: PPopovuch@gmail.com

Mykola MAIAK, Doctor of Sciences, Professor, Professor of the Department of Automobiles and Transport Technologies, Lutsk National Technical University, Lutsk, Ukraine, e-mail: maiak48@mail.ru\&. https://orcid.org/0000-0002-9749-980X

Pavlo POPOVYCH, Doctor of Sciences, Professor, Professor of Transport and Logistics department, West Ukrainian National University, Ternopil, Ukraine, e-mail: PPopovich@ukr.net. https://orcid.org/00000001-5516-852X

Oleksandr SHASHKEVYCH, Doctor of Philosophy, Associate Professor, West Ukrainian National University, Ternopil, Ukraine, e-mail: o.shashkevych@wunu.edu.ua . http://orcid.org/ 0000-0003-3642-1643

Yurii KOVAL, Master's student of the Department of Transport Technologies and Mechanics Ternopil Ivan Puluj National Technical University, Ternopil, Ukraine, e-mail: PPopovich@ukr.net.

DOI 10.36910/automash.v1i16.508 